\title{
Comparative digestive ability and rumen microbial community of N'Dama and N'Dama x Jersey cattle fed different diets
}

\author{
F.S. Nouala ${ }^{1 \#}$, S. Muetzel ${ }^{2}$, E. Hoffmann ${ }^{2}$ and K. Becker ${ }^{2}$ \\ ${ }^{1}$ Africa Union Interafrican Bureau for Animal Resources, Museum Hill, Westlands Rd, P.O. Box 30786-00100, \\ Nairobi, Kenya \\ ${ }^{2}$ Institute for Animal Production in the Tropics and Subtropics (480), University of Hohenheim, Fruwirthstreet, \\ 12 D-70593 Stuttgart, Germany
}

\begin{abstract}
Rumen fluid collected from three rumen fistulated N'Dama and three crossbred animals fed three different diets at medium supplementation level, was used to compare the plant cell wall degrading community of the two breeds of cattle. In vivo digestibility was also examined and compared using 12 animals (six of each breed) fed the same diets. The microbial community of the rumen was analyzed by $16 \mathrm{~S}$ rRNA hybridisation, using phylogenetic probes of different levels: a universal probe, domain-specific probes for Bacteria, Eukarya and Archaea, and probes targeting cellulolytic organisms: Chytridiomycetes, Fibrobacter spp., Ruminococcus albus and Ruminococcus flavefaciens. In vivo, organic matter (OM) and neutral detergent fibre (NDF) digestibility were significantly higher in N'Dama compared to crossbred animals when they were fed either baby corn stover and concentrate, or groundnut hay and moringa. In contrast, when the animals were fed groundnut hay and concentrate there was no difference in OM and NDF digestibility between the two breeds. Results of the microbial community analysis showed that RNA concentration of total Bacteria and Archaea was not affected by the breeds of animal, but were significantly affected by diet. The eukaryotic RNA concentration was higher in crossbred animals compared to the N'Dama and was not affected by the diet. Fibrobacter and R. flavefaciens RNA concentrations ( $\mu \mathrm{g} / \mathrm{mL}$ ) were significantly dependent on diet and breed. Ruminococcus albus and Chytridiomycetes RNA concentrations were neither affected by the breed, nor by the diet of the animals. This suggested that the differences between breeds observed in digestibility could be partially explained by the composition of the cell wall degrading community.
\end{abstract}

Keywords: In vivo digestibility, microbial community, ribosomal RNA probes, N’Dama, crossbreds

${ }^{\#}$ Corresponding author. E-mail: nouala.simplice@au-ibar.org

\section{Introduction}

The rumen microbiome (bacteria, protozoa and fungi) plays a key role in the digestibility of feed which influences feed intake and animal performance. It can be expected that the proportions of various nutrients that are available for absorption by the animal change according to the population sizes and activities of individual microbial species. Although the dependence of the ruminant on its ruminal microbiota is well known, there is still a lack of information regarding the comparative composition of the rumen microbial community of different breeds of ruminants. The attachment of microbes to feed particles (Forsberg \& Lam, 1977; Craig et al., 1987; Forsberg \& Cheng 1992; Weimer et al., 1999) and the morphological and physiological similarities among related microbial species have confounded the quantification of these microbes based on classical microscopy or cultivation methods. Moreover, cultivation also selects for cultivable strains and neglects the vast majority of microbes that cannot be grown in pure cultures.

Over the last decade the development of oligonucleotide probes for species-specific segments of $16 \mathrm{~S}$ rRNA has provided an unprecedented opportunity to characterize and quantify microbial communities in their natural environment without the need for cultivation (Fox et al., 1980; Stahl et al., 1985; Pace et al., 1986; Stahl et al., 1988; Shi et al., 2007; Goel et al., 2008). Oligonucleotide probe techniques have then been used to characterize rumen microbial communities of a single cow over time (Stahl et al., 1988), to investigate the competition among ruminal cellulolytic bacteria in a defined co-culture (Ondeyo et al., 1994; Shi \& Weimer, 1997), to examine the relationship among ruminal bacteria in vivo, and with regards to diet, 
feed digestion and animal production (Weimer et al., 1999; Hooper et al., 2002). However, these studies have not addressed the effects of the host animal's genetics on the rumen microbial communities in relation to differences in digestibility reported by several investigators (Givens \& Moss, 1994; Ranilla et al., 1998; Cruywagen et al., 2001; Akinbamijo et al., 2003).

Studies of microbial populations have raised many questions concerning the impact of host, environment and diet. Therefore the present study was undertaken to determine whether the plant cell wall degrading communities in the rumen vary between two cattle breeds (N'Dama and N'Dama x Jersey) kept under the same conditions and fed three different diets, in relation to in vivo digestibility.

\section{Materials and Methods}

Twelve bulls consisting of six N'Damas (152 $\pm 12 \mathrm{~kg}$ live weight, BW) and six Jersey x N'Dama crosses ( $295 \pm 10 \mathrm{~kg} \mathrm{BW}$ ), aged between $4-6$ years, were used for the study. Animal ethics approval was obtained from the International Trypanotolerance Centre (ITC) scientific committee in Gambia. The 12 bulls were housed individually in pens with concrete floors on an open-air platform. All animals had free access to a salt lick and access to water four times a day. Prior to the experiment, animals were dewormed with albendazole (Albenol ${ }^{\circledR}$ - 100, oral Inter Chemie, Holland) at the dose of $12 \mathrm{~mL} / \mathrm{kg}$ BW and were sprayed against ticks with Decatix (Cooper ${ }^{\circledR}$ Zimbabwe Pvt. LTD). They were also tested for trypanosomiasis using the dark ground buffy coat technique, and infected animals were treated with diminazene aceturate (Berenil® Hœchst A.G., Frankfurt Am Main, Germany) at a dose of $3.5 \mathrm{mg} / \mathrm{kg}$ BW. They were fed three different diets: Baby corn stover and concentrate (BCS:Co); groundnut hay and concentrate (GNH:Co) and groundnut hay and moringa leaf (GNH:Mo). The supplements (concentrate or moringa) represented $20 \%$ of the diet.

Table 1 Chemical composition of test diets (g/kg dry matter)

\begin{tabular}{lcccc}
\hline & OM & CP & NDF & ADF \\
\hline Baby corn stover \& Concentrate & 90.7 & 10.8 & 60.8 & 34.8 \\
Groundnut hay \& Concentrate & 89.4 & 16.2 & 49.2 & 41.4 \\
Groundnut hay \& Moringa leaf & 85.9 & 16.8 & 33.8 & 26.7
\end{tabular}

OM - organic matter; CP - crude protein; NDF - neutral detergent fibre; ADF - acid detergent fibre.

The feed was offered on a dry matter basis at $2.5 \% \mathrm{BW}$ in two equal daily portions in the morning and in the afternoon to ensure constant availability. The roughage (basal diet) was only offered after an animal had completely consumed the supplement. During the adaptation period the average feed intake was measured individually and the bulls were offered this quantity plus $10-20 \%$ during the data collection period. Cleaning of the pens, removal and weighing of leftovers from the previous day were done daily before feeding. Representative samples of feed offered and of feed refused were taken daily for dry matter determination and bulked per breed for crude nutrients analysis.

After a 14-day adaptation period, faeces were manually collected immediately after being voided and sub-sampled, and weighed at 08:00 and 20:00. The dry matter was determined on a daily basis, and 5\% of the representative faeces voided, were sampled from each animal, kept in a freezer and bulked on a weekly basis until required for further analysis. The collection period lasted 10 days.

Samples for microbial community analysis were collected from six rumen fistulated animals (three N'Damas and three N'Dama x Jersey crossbreds). In the morning before feeding rumen fluid and digesta were collected, strained and squeezed though a $100 \mu \mathrm{m}$ pore size nylon bag in a prewarmed thermos flask. Laboratory handling of rumen fluid was done under continuous flushing with $\mathrm{CO}_{2}$ to maintain anaerobic conditions. Approximately $300 \mu \mathrm{L}$ rumen fluid were put into a $2 \mathrm{~mL}$ screwcap cup containing $600 \mu \mathrm{L}$ phenol (pH 5), and stored at $-25^{\circ} \mathrm{C}$. Every two months samples were sent to the University of Hohenheim where they were stored at $-80^{\circ} \mathrm{C}$. 
Animals were fed the same diets as used in the in vivo digestibility trial. Samples were collected before morning feeding from each fistulated animal. For each diet, samples were collected after a 14-day adaptation period for three consecutive days in triplicate per fistulated animal.

Total RNA was extracted using the modified (Muetzel \& Becker, 2002) low pH hot phenol extraction procedure described by Stahl et al. (1988). To each sample containing phenol, $270 \mu \mathrm{L}$ of a buffer (pH 5.1; 50 $\mathrm{mM}$ sodium acetate, $10 \mathrm{mM}$ EDTA, pH 5.1), $30 \mu \mathrm{L}$ SDS (20\% w/v) and $1 \mathrm{~g}$ zircona silica beads ( $0.1 \mathrm{~mm})$ were added. Cells were then lysed by beating the samples in a beat mill (Bartlesville, OK, USA) and shaken for $2 \mathrm{~min}$. Samples were placed into a water-bath at $60{ }^{\circ} \mathrm{C}$ for $10 \mathrm{~min}$ and the beating was repeated. Approximately $300 \mu \mathrm{L}$ chloroform was added to the samples which were shaken vigorously and then incubated at room temperature for $5 \mathrm{~min}$. The incubation was repeated after another vigorous shaking. Aqueous and organic phases were separated by centrifugation (10 $\left.000 \mathrm{x} \mathrm{g}, 5 \mathrm{~min}, 4^{\circ} \mathrm{C}\right)$, and the aqueous phase was transferred into a new vial containing $300 \mu \mathrm{L}$ of $7.5 \mathrm{M}$ ammonium acetate and $900 \mu \mathrm{L}$ of isopropanol. Nucleic acids were precipitated at $-20{ }^{\circ} \mathrm{C}$ overnight and recovered by centrifugation (16 $000 \mathrm{x}$ $\mathrm{g}, 10 \mathrm{~min}, 4^{\circ} \mathrm{C}$ ). Then the supernatant was discarded and the samples were washed in $80 \%$ ethanol. Nucleic acids were dissolved in $100 \mu \mathrm{L}$ double distilled $\mathrm{H}_{2} \mathrm{O}$ and samples were stored at $-80{ }^{\circ} \mathrm{C}$.

The quantification and the integrity of the RNA extracts were evaluated by agarose gel electrophoresis. Approximately $10 \mu \mathrm{L}$ of nucleic acids were mixed with $10 \mu \mathrm{L}$ of a sample loading buffer ( $40 \%$ saccharose and $0.05 \%$ bromophenol blue) and $4 \mu \mathrm{L}$ of the mixture were loaded onto a $1.4 \%$ agarose gel. 16S Ribosomal RNAs (gels also showed the other rRNAs) were separated in a horizontal electrophoresis chamber containing a TBE buffer ( $0.1 \mathrm{M}$ tris-base, $0.083 \mathrm{M}$ boric-acid and $1 \mathrm{mM}$ EDTA pH 8 ) at $200 \mathrm{~V}$ for $2 \mathrm{~h}$. After separation, the gels were stained for $30 \mathrm{~min}(1 \mu \mathrm{g} / \mathrm{mL}$ ethidium bromide), and destained for $30 \mathrm{~min}$ in the TBE buffer. Each gel contained six lanes of known concentrations of RNA (i.e. standards) that served as a calibration for an initial quantification of the RNA recovered for the calculation of the dilutions prepared for membrane hybridisation.

Membrane hybridizations were carried out as described in Stahl et al. (1988). The oligonucleotide probes used were custom synthesized by the Amersham Pharmacia Biotech, (Freiburg, Germany) and targeted Fibrobacter spp. (Stahl et al. 1988), Ruminococcus albus and Ruminococcus flavefaciens (Odenyo et al., 1994), total bacteria (Amann et al., 1990), the Chytridiomycetes (Dore et al., 1993), total Archaea (Amann et al., 1990) total eukaryotes (Hicks et al., 1992) and total 16S rRNA (Zheng et al., 1996) (Table 2).

Table 2 Oligonucleotide probe sequence with empirically determined thermal denaturation temperature (td) used in the experiment (Muetzel et al., 2003).

\begin{tabular}{lll}
\hline Target & Sequence (‘5-`3) & $\begin{array}{l}\text { Wash temperature } \\
\left({ }^{\circ} \mathrm{C}\right)\end{array}$ \\
\hline All organisms & GAC GGG CGG TGT GTA CAA & 44 \\
Bacteria & GCT GCC TCC CGT AGG AGT & 54 \\
Eukarya & TAC AAA GGG CAG GGA C & 42 \\
Archaea & GTG CTC CCC CGC CAA TTC CT & 56 \\
Chytridiomycetes & GTA CAC ACA ATG AAG TGC ATA AAG G & 43 \\
Fibrobacter & AAT CGG ACG CAA GCT CAT CCC & 56 \\
R. flavefaciens & AAC GGC AGT CCC TTT AG & 46 \\
R. albus & GTC AAC GGC AGT CCT GCT A & 46 \\
\hline
\end{tabular}

R. albus - Ruminococcus albus; Ruminococcus flavefaciens - R. flavefaciens.

The RNA samples were denatured with three volumes of glutaraldehyde $(2 \% \mathrm{v} / \mathrm{v})$ and diluted to approximately $2 \mathrm{ng} / \mu \mathrm{L}$ with dilution water $(0.2 \mathrm{ng} / \mathrm{mL}$ bromophenol blue) $10 \mu \mathrm{g}$ poly A. Then $50 \mu \mathrm{L}$ of these dilutions were applied to a positively charged nylon membrane (Magna Charge, Micron Separation 
Inc., Westboro, Ma) under slight vacuum using a Minifold II $^{\mathrm{TM}}$ slot blotter (Schleicher and Schüll, Horb, Germany) in triplicate. For quantification purposes each membrane contained standards (i.e. a reference series) with known amounts of target RNA (Figure 1). Membranes were air-dried and RNA was fixed by baking at $80{ }^{\circ} \mathrm{C}$ for $1 \mathrm{~h}$. Membranes were transferred to hybridization bottles and $3 \mathrm{~mL}$ of hybridization buffer were added per membrane. Membranes then were prehybridised at $40^{\circ} \mathrm{C}$ for $1 \mathrm{~h}$.

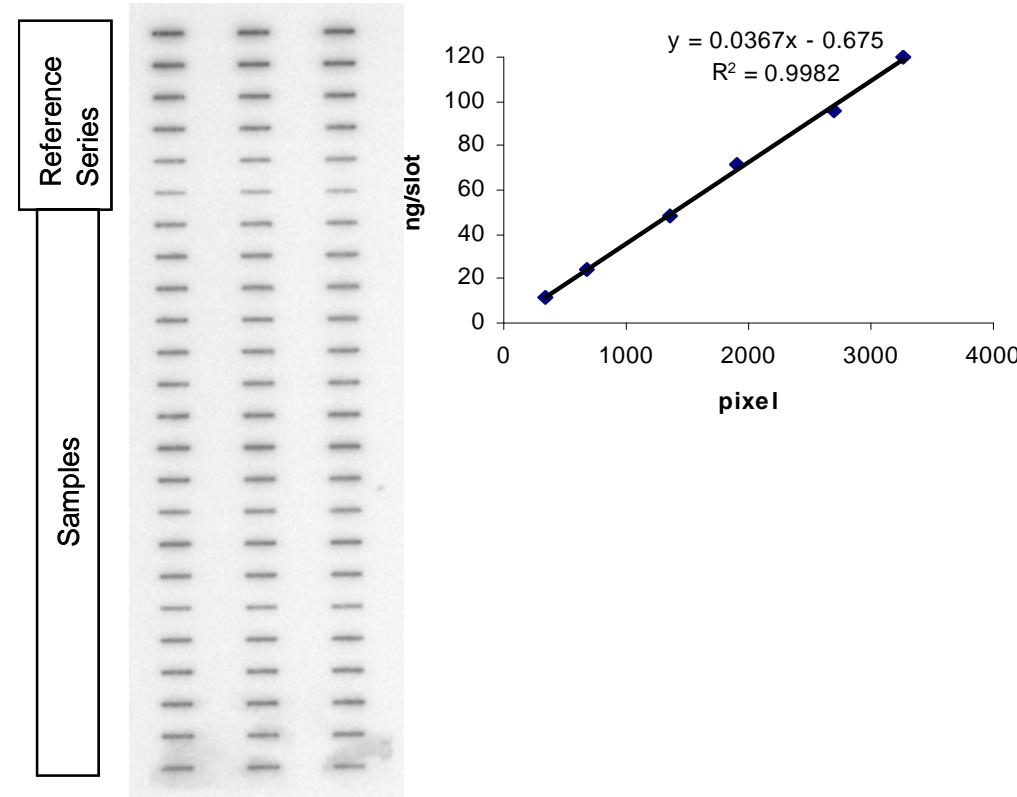

Figure 1 Membrane layout used for hybridisations. Each membrane contained 24 slots, the first six slots were hybridised with a universal probe using Escherichia coli as a reference strain, and the remaining 18 slots contained RNA from a member of the target group.

Probes were labelled with 32P-ATP (MP Biomedicals Inc., Eschwege, Germany) using T4 nuclease transferase (Amersham Pharmacia Biotech, Freiburg, Germany). The labelled probes were purified with spin columns (QIA Quick spin, Queen GmbH, Holden, Germany) and then added to the appropriate amount of hybridization buffer ( $3 \mathrm{~mL}$ per membrane). The pre-hybridization buffer was discarded and the hot buffer was added to the membranes. Hybridization was carried out overnight at $40{ }^{\circ} \mathrm{C}$. Then the membranes were removed from the bottles and placed into a wash solution (SSC and 1\% SDS), which was preheated to the probe specific wash temperature. After $15 \mathrm{~min}$ the membranes were transferred and kept for another $15 \mathrm{~min}$ in the fresh wash solution. There-after the membranes were air dried, covered with saran wrap and exposed to imaging plates (Type BAS-III, Fuji Photo Co., Ltd, Japan). The imaging plates were scanned in a phosphorus imager (BAS 1000, Raytest Isotopenmeßgeräte GmbH, Straubenhardt, Germany) and the resulting digital images were analyzed using the programme, Aida (Raytest Isotopenmeßgeräte GmbH, Straubenhardt, Germany).

Data were subjected to analysis of variance using the GLM procedure of SAS. The model used was:

$$
Y_{i j}=\mu+B_{i}+D_{j}+E_{i j} \text {, }
$$

Where $Y_{i j}$ represented the dependent variable for breed $B_{i}$ (1 to 2), for diet $D_{j}$ (1 to 3), $\mu$ the mean for the variable and $\mathrm{E}_{\mathrm{ij}}$, the error associated with the observation $\mathrm{ij}$.

\section{Results}

The results of the in vivo organic matter digestibility (OMD) and neutral detergent fibre digestibility (NDFD) are shown in Table 3. When animals were fed BCS:Co or GNH:Mo, the OM and NDF digestibility were significantly higher in N'Dama cattle compared to the crossbreds. The difference was higher on the BCS:Co (7\%) compared to the 4\% on the GNH:Mo diet. However, when GNH:Co was fed to both the N'Dama and crossbred cattle, there was no significant difference in both OMD and NDFD between the two breeds. 
Table 3 Mean ( \pm s.d.) organic matter digestibility (OMD) and neutral detergent fibre digestibility (NDFD observed in two cattle breeds (N’Dama and N’Dama x Jersey crossbred) fed three different diets

\begin{tabular}{lllllll}
\hline \multirow{2}{*}{ Diet } & \multicolumn{3}{l}{ OMD (\%DM) } & \multicolumn{4}{l}{ NDFD (\%DM) } \\
\cline { 2 - 7 } & N'Dama & Crossbred & P value & N'Dama & Crossbred & P value \\
\hline Baby corn stover \& Concentrate (BCS:Co) & $63.2 \pm 1$ & $55.9 \pm 2$ & $<0.01$ & $58.0 \pm 1$ & $51.5 \pm 2$ & $<0.01$ \\
Groundnut hay \& Concentrate (GNH: Co) & $64.9 \pm 1$ & $66.6 \pm 1$ & 0.06 & $50.2 \pm 2$ & $52.0 \pm 2$ & 0.06 \\
Groundnut hay \& Moringa leaf (GNH: Mo) & $66.8 \pm 1$ & $63.5 \pm 1$ & $<0.05$ & $45.9 \pm 2$ & $41.7 \pm 1$ & $<0.05$ \\
\hline
\end{tabular}

The overall results for the microbial community analysis showed a huge variation among animals of the same breed. The bacterial RNA concentration $(\mu \mathrm{g} / \mathrm{mL}$ of rumen fluid) was not significantly affected by the breed of animal. However, it was significantly $(\mathrm{P}<0.05)$ affected by diet (Table 4$)$. The bacterial RNA concentration was higher in the groundnut based diets compared to the baby corn stover based diet. There was no significant breed $\mathrm{x}$ diet interaction.

The probe used to target all rumen eukaryotes did not differentiate between protozoa and anaerobic rumen fungi. When averaged for all the diets, the eukaryotic RNA concentrations ( $\mu \mathrm{g} / \mathrm{mL}$ of rumen fluid) were significantly $(\mathrm{P}<0.05)$ higher in crossbred animals compared to the N'Dama breed $(7 \mathrm{vs} .4 \mu \mathrm{g} / \mathrm{mL}$, respectively). However, diet had no effect on the microbial populations between the breeds (Table 4). When averaged for both breeds, there was no dietary effect, although it tended to be higher for GNH:Mo (4.63, 5.02 and $6.10 \mu \mathrm{g} / \mathrm{mL}$ for BCS:Co, GNH:Co and GNH:Mo, respectively). The breed $\mathrm{x}$ diet interaction was also non significant.

Table 4 Least-square means ( \pm s.d.) RNA concentrations of Bacteria, Eukarya and Archaea $(\mu \mathrm{g} / \mathrm{mL})$ in rumen fluid of two cattle breeds fed different diets

\begin{tabular}{|c|c|c|c|c|c|c|c|c|}
\hline \multirow{2}{*}{ Organisms } & \multirow{2}{*}{ Breed } & \multicolumn{3}{|c|}{ Diets } & \multirow[t]{2}{*}{ Breed } & \multirow[t]{2}{*}{ Diet } & \multirow[t]{2}{*}{ Day } & \multirow{2}{*}{$\begin{array}{c}\text { Breed } \\
\text { x } \\
\text { Diet }\end{array}$} \\
\hline & & BCS:Co & GNH:Co & GNH:Mo & & & & \\
\hline \multirow{2}{*}{ Bacteria } & Crossbred & $62.52 \pm 39.0$ & $124.36 \pm 63.0$ & $128.85 \pm 58.0$ & \multirow{2}{*}{ NS } & \multirow{2}{*}{$<0.05$} & \multirow{2}{*}{$<0.05$} & \multirow{2}{*}{ NS } \\
\hline & N'Dama & $97.69 \pm 49.0$ & $110.69 \pm 43.0$ & $98.89 \pm 40.0$ & & & & \\
\hline \multirow{2}{*}{ Archaea } & Crossbred & $0.89 \pm 0.9$ & $2.08 \pm 1.7$ & $1.93 \pm 0.7$ & \multirow{2}{*}{ NS } & \multirow{2}{*}{$<0.01$} & \multirow{2}{*}{ NS } & \multirow{2}{*}{ NS } \\
\hline & N'Dama & $1.06 \pm 0.8$ & $1.75 \pm 0.8$ & $1.71 \pm 07$ & & & & \\
\hline \multirow{2}{*}{ Eukaryotes } & Crossbred & $6.30 \pm 5$ & $6.62 \pm 4$ & $7.14 \pm 6$ & \multirow{2}{*}{$<0.05$} & \multirow{2}{*}{ NS } & \multirow{2}{*}{ NS } & \multirow{2}{*}{ NS } \\
\hline & N'Dama & $3.36 \pm 3$ & $3.56 \pm 3$ & $5.13 \pm 4$ & & & & \\
\hline
\end{tabular}

BCS:Co = Baby corn stover and concentrate; GNH:Co = Groundnut hay and concentrate; GNH:Mo = Groundnut hay and moringa; NS = non significant.

Contrary to the eukaryotic RNA concentration, the archaeal (i.e. methanogens) RNA concentration was significantly affected by the diet of the animals $(\mathrm{P}<0.01)$. The archaeal RNA concentration was lower in the baby corn stover diet compared to the groundnut hay diet ( $1 \mathrm{vs} .2 \mu \mathrm{g} / \mathrm{mL}$, respectively) and was higher with GNH:Co compared to the GNH:Mo diet. However, the difference between the two breeds was not significant and no breed $\mathrm{x}$ diet interaction was observed. 
Table 5 Least-square means ( \pm s.d.) RNA concentrations of Chytridiomycetes Fibrobacter spp., Ruminococcus albus and Ruminococcus flavefaciens $(\mu \mathrm{g} / \mathrm{mL})$ in rumen fluid of two cattle breeds fed different diet

\begin{tabular}{|c|c|c|c|c|c|c|c|c|}
\hline \multirow[t]{2}{*}{ Organisms } & \multirow[t]{2}{*}{ Breed } & \multicolumn{3}{|c|}{ Diets } & \multirow[t]{2}{*}{ Breed } & \multirow[t]{2}{*}{ Diet } & \multirow[t]{2}{*}{ Day } & \multirow[t]{2}{*}{$\begin{array}{l}\text { Breed } \\
x \text { Diet }\end{array}$} \\
\hline & & BCS:Co & GNH:Co & GNH:Mo & & & & \\
\hline \multirow{2}{*}{ Chytridiomycetes } & Crossbred & $0.17 \pm 0.1$ & $0.21 \pm 0.2$ & $0.36 \pm 0.2$ & \multirow{2}{*}{ NS } & \multirow{2}{*}{ NS } & \multirow{2}{*}{ NS } & \multirow{2}{*}{ NS } \\
\hline & N'Dama & $0.16 \pm 0.2$ & $0.14 \pm 0.1$ & $0.19 \pm 0.2$ & & & & \\
\hline \multirow{2}{*}{ Fibrobacter spp. } & Crossbred & $0.68 \pm 0.4$ & $0.42 \pm 0.2$ & $0.39 \pm 0.1$ & \multirow{2}{*}{ NS } & \multirow{2}{*}{$<0.0001$} & \multirow{2}{*}{ NS } & \multirow{2}{*}{$<0.05$} \\
\hline & N'Dama & $1.29 \pm 0.9$ & $0.33 \pm 0.1$ & $0.31 \pm 0.1$ & & & & \\
\hline \multirow{2}{*}{ R. albus } & Crossbred & $0.40 \pm 0.6$ & $0.69 \pm 0.4$ & $0.61 \pm 0.3$ & \multirow{2}{*}{ NS } & \multirow{2}{*}{ NS } & \multirow{2}{*}{$<0.01$} & \multirow{2}{*}{ NS } \\
\hline & N'Dama & $0.68 \pm 0.4$ & $0.59 \pm 0.2$ & $0.47 \pm 0.3$ & & & & \\
\hline \multirow{2}{*}{ R. flavefaciens } & Crossbred & $0.11 \pm 0.1$ & $0.10 \pm 0.1$ & $0.08 \pm 0.1$ & \multirow{2}{*}{ NS } & \multirow{2}{*}{$<0.05$} & \multirow{2}{*}{ NS } & \multirow{2}{*}{$<0.05$} \\
\hline & N'Dama & $0.22 \pm 0.2$ & $0.05 \pm 0.1$ & $0.05 \pm 0.1$ & & & & \\
\hline
\end{tabular}

BCS:Co = Baby corn stover and concentrate; GNH:Co = Groundnut hay and concentrate; GNH:Mo = Groundnut hay and moringa; NS= non significant.

Four cell wall degrading organisms were also targeted (Chytridiomycetes, Fibrobacter spp., R. albus and $R$. flavefaciens). When averaged for all the diets, there was no significant difference between the two breeds in the RNA concentration of the four cell degrading organisms (Table 5). However, the RNA concentrations of Fibrobacter and $R$. flavefaciens were significantly affected by diet and a significant $(\mathrm{P}<0.05)$ breed $\mathrm{x}$ diet interaction was observed in the RNA concentration of these organisms. When averaged for all the breeds, the RNA concentrations of Fibrobacter and $R$. flavefaciens were respectively 3 and 2 times higher when animals were fed the baby corn diet than the groundnut hay based diets. Moreover, when the animals were fed BCS:Co, the N'Dama breed had higher Fibrobacter $(\mathrm{P}<0.05)$ and $R$. flavefaciens ( $\mathrm{P}<0.05)$ RNA concentrations compared to the crossbred animals, whereas on groundnut based diets, there was no significant difference in Fibrobacter and $R$. flavefaciens RNA concentrations $(\mu \mathrm{g} / \mathrm{mL})$ between the two breeds.

The $R$. albus RNA concentration was neither influenced by the diet, nor by breed. Nevertheless, when animals were fed BCS:Co, the difference in $R$. albus RNA concentration tended to be in favour of the N'Dama breed $(\mathrm{P}=0.06)$, whereas on the groundnut hay based diets, the crossbred animals tended to have a higher RNA concentration of $R$. albus $(\mathrm{P}=0.2)$.

With the RNA concentration of Chytridiomycetes (Table 5), there was no significant affect of animal breed and diet. Moreover, no significant breed $\mathrm{x}$ diet interaction was observed. In general the Chytridiomycetes accounted for 3\% to 5\% of the total eukaryotic population 16S rRNA.

\section{Discussion}

Rumen microorganisms play a key role in the digestibility of feed, and this affects feed intake and animal performance. The effect of diet on composition, density and activity of the rumen microbiome has been investigated intensively (McAllister, 2000; Michalet-Doreau et al., 2002; Muetzel et al., 2003). In the present study these effects were also observed in Fibrobacter, $R$. flavefaciens, total bacterial and archaeal RNA concentrations. However, the effect of different breeds of cattle on the rumen microbial community is not well documented. In the present study there was no significant difference in RNA concentration of bacteria and Archaea between the two breeds and no breed $\mathrm{x}$ diet interaction was observed. The higher RNA concentration of eukaryotes observed in the crossbred cattle was most probably the result of a higher rumen protozoal RNA concentration since there was no difference between the two breeds in Chytridiomycetes RNA concentration. Protozoa have been reported to reduce intestinal protein supply (Muetzel et al., 2003). It could therefore be speculated that the low concentration of protozoa observed in rumen fluid of the native 
N'Dama breed would increase the efficiency of protein utilisation and this could support a better conserving of nitrogen, and be related to the better digestibility observed in native cattle breeds compared to exotic breeds (Norton et al., 1979).

The absolute total of cell wall degrading bacteria (consisting of the culturable species, Fibrobacter spp., $R$. albus and $R$. flavefaciens, but excluding uncultured species) was significantly higher in the N'Dama breed compared to the crossbred cattle. This difference corresponded to the difference (in favour of N'Dama) in in vivo OM and NDF digestibility when data were averaged for all the diets. However, there was a significant breed $\mathrm{x}$ diet interaction in Fibrobacter spp. and $R$. flavefaciens RNA concentrations. On the BCS:Co and GNH:Co diets, in vivo organic matter and NDF digestibility showed the same trend in Fibrobacter spp. and R. flavefaciens RNA concentrations. However, with moringa as supplement N'Dama cattle had in contrast the highest digestibility despite the absence of significant differences in RNA concentrations $(\mu \mathrm{g} / \mathrm{mL})$ of the targeted cell wall degrading microbial community between the two breeds. The highest digestibility observed in this case may be related to the lowered protozoa concentration and consequently to better nitrogen sparing, as reported by Norton et al. (1979). The two other cell wall degrading organisms targeted (i.e. R. albus and Chytridiomycetes), were not related to in vivo digestibility data. Stahl et al. (1988), Weimer et al. (1999) and Michalet-Doreau et al. (2002) did not find any relationship between digestion results and microbial ecosystem composition, determined using oligonucleotide probes to rRNA. The absence of this relationship may be due to the low identified bacterial proportion with the rRNA probes used (Michalet-Doreau et al., 2002). Within the cell wall degrading community, the RNA concentration of Chytridiomycetes was not affected by the diet and breed of the animals. However, Chytridiomycetes was surprisingly high when animals were fed moringa as supplement; they represented $19 \%$ and $25 \%$ of the cellulolytic rRNA in N'Dama and crossbreds, respectively. The Chytridiomycetes are known for their high activity in cell wall breakdown (Williams \& Withers, 1991; Lee et al., 2000; Muetzel et al., 2003; Mehmet et al., 2005) and were expected to be higher on groundnut hay diets with a low NDF digestibility.

The RNA concentration of Fibrobacter and the ruminococci showed elevated amounts on the stover based diet, almost four times more than on the groundnut hay based diet. This was not surprising because these two organisms are recognized as the most active cell wall degrading species (Li \& Heath, 1993; Malburg \& Forberg, 1993). Fibrobacter is a widely examined rumen organism and the basic work with 16 rRNA targeted probes was done by Stahl et al. (1988) using a probe specific for this cell wall degrading organism. The proportion of Fibrobacter in the rumen fluid from our study showed a large variability ranging from 0.3 to $1.3 \%$ of the total bacterial RNA, with the lowest proportion in the groundnut hay based diet. These proportions are within the range reported by Muetzel et al. (2003) and much lower than those of Stahl et al. (1988). The difference between the data could be explained by the difference in the diet and more importantly the difference in the collection time. Our samples were collected before morning feeding (about $12 \mathrm{~h}$ after feeding), while those of Stahl et al. (1988) were collected $6 \mathrm{~h}$ after feeding. Species belonging to the genus Fibrobacter appeared to be the dominant cellulolytic bacteria targeted on stover based diets as they represented $50 \%$ to $55 \%$ of the cellulolytic rRNA, and the ruminococci ( $R$. albus and $R$. flavefaciens) were the dominant (48 - 58\%) bacteria on groundnut hay based diets. Weimer et al. (1999) and Martin et al. (2001) reported a higher proportion of the two ruminococci compared to Fibrobacter in the rumen microbial ecosystem of dairy cows, with $R$. albus as the dominant species. There was no difference in the proportion of the Ruminococcus and Fibrobacter relative to the total cell wall degrading community between the two breeds.

\section{Conclusions}

Differences in digestibility and most probably in productivity between breeds could be correlated to (and may be partially manifested through) a divergent community structure of rumen microbes. That, in turn, indicates that animals of different breeds might have a 'genetic background' that favours the establishment of a certain community, even if the animals are kept under identical conditions. This relationship should be investigated by more advanced molecular techniques. 


\section{References}

Akinbamijo, O.O., Nouala, S., Sanyang, F.B. \& Smith, O.B., 2003. Utilization of horticultural residues by N’Dama cattle and their crosses in The Gambia. Livest. Prod. Sci. 80, 221-228.

Amann, R.I., Krumholz, L. \& Stahl, D.A., 1990. Fluorescent oligonucleotide probing of whole cells for determinative, phylogenetic and environmental studies in microbiology. J. Bacteriol. 172, 762-770.

Craig, W.M., Broderick, G.A. \& Ricker, D.B., 1987. Quantification of microorganisms associated with the particulate phase of ruminal digesta. J. Nutr. 117, 56-62.

Cruywagen, C.W., Strickland, N. \& Schoeman, S.J., 2001. Comparison between Holstein and Jersey cows in post-prandial rumen $\mathrm{pH}$ and VFA concentration. J. Anim. Sci. 79, Suppl. 1.

Dore, J., Brownlee, A.G., Millet, L., Virlogeux, I., Saigne, M., Fonty, G. \& Gouet, P., 1993. Ribosomal DNA-targeted hybridization probes for the detection identification and quantification of anaerobic rumen fungi. Proc. Nutr. Soc. 52, 176-176.

Forsberg, C.W. \& Cheng, K.J., 1992. Molecular strategies to optimise forage and cereal digestion by ruminants. In: Biotechnology and Nutrition. Eds Bills, D.D. \& Kung, S.D., Butterworth Heinmann, Stoneham, UK. pp. 107-147.

Forsberg, C.W. \& Lam, K., 1977. The use of adenosine-5'-triphosphate as an indicator of microbiota biomass in rumen contents. Appl. Environ. Microbiol. 33, 528-537.

Fox, G.E., Stackebrant, E., Hespell, R.B., Gibson, J., Maniloff, J., Dyer, T.A., Wolfe, R.S., Gupta, R., Bonen, L., Lewis, B.J., Stahl, D.A., Luehrson, K.R., Chen, K.N. \& Woese, C.R., 1980. The phylogeny of prokaryotes. Science 209, 457-463.

Givens, D.I. \& Moss, A.R., 1994. Effect of breed, age and bodyweight of sheep on the measurement of apparent digestibility of dried grass. Anim. Feed Sci. Technol. 46, 155-162.

Goel, G., Makkar, H.P.S. \& Becker, K., 2008. Changes in microbial community structure, methanogenesis and rumen fermentation in response to saponin-rich fractions from different plant materials. J. Appl. Microbiol. 105, 770-777.

Hicks, R.E., Amann, R. \& Stahl, D.A., 1992. Dual staining of natural bacterioplankton with 4', 6-Diamdino2-Phenylindole and fluorescent oligonucleotide probes targeting kingdom-level 16S rRNA sequences. Appl. Environ. Microbiol. 58, 2158-2163.

Hooper, L.V., Midtvedt, T. \& Gordon, J.I., 2002. How host microbial interactions shape the nutrient environment of the mammalian intestine. Ann. Rev. Nutr. 22, 283-307.

Lee, S., Ha, S.J.K. \& Cheng, K.-J., 2000. Relative contributions of bacteria, protozoa, and fungi to in vitro degradation of orchard grass cell walls and their interactions. Appl. Environ. Microbiol. 66, 3807-3813.

Li, J. \& Heath, I.B., 1993, Chytridiomycetous gut fungi, often overlooked contributors to herbivore digestion. Can. J. Microbiol. 39, 1003-1013.

Malburg, L.M. \& Forsberg, C.W., 1993. Fibrobacter succinogenes S85 possesses at least nine distinct glucanase genes. Can. J. Microbiol. 39, 882-891.

Martin, C., Millet, L., Fonty, G. \& Michalet-Doreau, B., 2001. Cereal supplementation modified the fibrolytic activity but not the structure of the cellulolytic bacterial community associated with rumen solid digesta. Reprod. Nutr. Dev. 41, 413-424.

McAllister, T., 2000. Learning more about rumen bugs: genetic and environmental factors affecting rumen bugs. Southern Alberta Beef Review 2 (1).

Mehmet Sait, E., Emin, Z.S. \& Üsmail, A., 2006. Effects of sequential sub-culturing on the survival and enzyme activity of Neocallimastix hurleyensis. Turk. J. Biol. 30, 157-162.

Michalet-Doreau, B., Fernandez, I. \& Fonty, G., 2002. A comparison of enzymatic and molecular approaches to characterize the cellulolytic microbial ecosystems of the rumen and the caecum. J. Anim. Sci. 80, 790-796.

Muetzel, S. \& Becker, K., 2002. An optimised RNA extraction protocol for rumen samples. Reproduction Nutrition Development 42: Suppl. 1 S8.

Muetzel, S., Hoffmann, E.M. \& Becker, K., 2003. Supplementation of barley straw with Sesbania pachycarpa leaves in vitro: effects on fermentation variables and rumen microbial population structure quantified by ribosomal RNA-targeted probes. Br. J. Nutr. 89, 445-453.

Norton, B.W., Moran, J.B. \& Nolan, J.V., 1979. Nitrogen metabolism in Brahman cross, buffalo Banteng and shorthorn steers fed low quality roughage. Aust. J. Agric. Res. 30, 341-351. 
Odenyo, A.A., Mackie, R.I., Stahl, D.A. \& White, B.A., 1994. The use of 16rRNA-targeted oligonucleotide probes to study competition between ruminal fibrolytic bacteria: pure culture studies with cellulose and alkaline peroxide-treated wheat straw. Appl. Environ. Microbiol. 60, 3697-3703.

Ranilla, M.J., Lopez, S., Giraldez, F.J., Valdes, C. \& Carro, M.D., 1998. Comparative digestibility and digesta flow kinetics in two breeds of sheep. Anim. Sci. 66, 389-396.

Shi, Y. \& Weimer, P.J., 1997. Competition for cellulose among three predominant ruminal cellulolytic bacteria under substrate-excess and substrate-limited conditions. Appl. Environ. Microbial. 63, 734-742.

Shi, P.J., Meng, K., Zhou, Z.G., Wang, Y.R., Diao, Q.Y. \& Yao, B., 2008 The host species affects the microbial community in the goat rumen. Lett. Appl. Microbiol. 46, 132-135.

Stahl, D.A., Lane, D.L. Olsen, G.J. \&. Pace, N.R., 1985. Characterisation of Yellowstone hot spring microbial community by 5 S ribosomal RNA sequences. Appl. Microbiol. 49, 1379-1384.

Stahl, D.A., Flesher, B., Mansfield, H.R. \& Montgomery, L., 1988. Use of phylogenetically based hybridization probes for studies of rumen microbial ecology. Appl. Environ. Microbiol. 54, 1079-1094.

Weimer, P.J., Waghorn, G.C., Odt, C.L. \& Mertens, D.R., 1999. Effect of diet on populations of three species of ruminal cellulolytic bacteria in lactating dairy cows. J. Dairy Sci. 82, 122-134.

Williams, A.G. \& Withers, S.E., 1991. Effect of ciliate protozoa on the activity of polysaccharide-degrading enzymes and fibre breakdown in the rumen ecosystem. J. Appl. Microbiol. 70, 144-155.

Zheng, D.D., Alm, E.W., Stahl, D.A. \& Raskin, L., 1996. Characterization of universal small-subunit rRNA hybridization probes for quantitative molecular microbial ecology studies. Appl. Environ. Microbiol. 62, 4504-4513. 